\title{
CONTROLLING DEFORESTATION IN THE BRAZILIAN AMAZON: REGIONAL ECONOMIC IMPACTS AND LAND-USE CHANGE
}

Terciane Sabadini Carvalho (PPGDE/UFPR)

Edson Paulo Domingues (Cedeplar/UFMG)

\begin{abstract}
Brazil confirmed targets for reducing greenhouse gas emissions in 2008, including an 80\% reduction in deforestation in the Amazon by 2020. With this in mind, we investigated the trade-off between environmental conservation and economic growth in the Amazon. The aim of this study is to project the economic losses and land-use changes resulting from a policy to control deforestation and the rise in land productivity that is necessary to offset those losses. We developed a Dynamic Interregional Computable General Equilibrium Model for 30 Amazon regions with a land module allowing conversion between types of land. The results have shown that the most affected regions would be soybeans and cattle producers as well as regions dominated by family farms. To offset these impacts, it was estimated that an annual gain of land productivity of approximately $1.4 \%$ would be required.

Key words: computable general equilibrium, Brazil, Amazon, land-use change, deforestation, productivity

Resumo: O Brasil confirmou metas para a redução de emissões de gases de efeito estufa em 2008, incluindo $80 \%$ de redução no desmatamento na Amazônia até 2020. Com isto em mente, este artigo investiga o trade-off entre conservação ambiental e crescimento econômico na Amazônia. O objetivo do artigo é projetar as perdas econômicas e mudanças no uso da terra decorrentes de uma política de controle de desmatamento, assim como o aumento na produtividade da terra necessário para compensar essas perdas. Desenvolveu-se um Modelo de Equilíbrio Geral Computável Inter-regional Dinâmico para 30 mesorregiões da Amazônia com um módulo de uso da terra que permite a conversão entre os tipos de terra. Os resultados mostraram que as regiões mais afetadas seriam aquelas produtoras de soja e gado assim como as regiões onde predomina a agricultura familiar. Para anular esses impactos, foi estimado que um ganho anual de produtividade da terra de aproximadamente 1,4\% seria necessário.
\end{abstract}

Palavras-chave: equilíbrio geral computável, Brasil, Amazônia, mudança no uso da terra, desmatamento, produtividade

JEL Code: Q15; C68; Q58; R13

Área 11 - Economia Agrícola e do Meio Ambiente

\section{Introduction and Background}

Deforestation in the Brazilian Amazon has attracted the attention of researchers and public authorities towards methods and policies that involve both its measurement and control. In addition to the importance of conserving one of the largest biomes of ecological diversity (Peres et al., 2010) and harboring the largest area of primary forest in the world - 35\% of the world's total primary forest (FAO, 2010) - the region has become the target of policies to reduce deforestation because it constitutes an important measure in the mitigation of emissions of greenhouse gases (GHG).

The Amazon region has already lost about of $15 \%$ of its total forest area. However, according to INPE (2013), there was a decline in deforestation rates from 2004 to 2012. This decline is related to economic factors, such as the reduction in international soybean and beef prices and the appreciation of the Brazilian currency, which discouraged exports. Another contributing factor is the increased surveillance of the Amazon, which has been made possible by the implementation of government programs, such as the Action Plan for the Prevention and Control of Deforestation in the Amazon (Soares-Filho et al., 2009; Assunção et al., 2012).

Arima and Verissimo (2002) pointed out that the three major forms of deforestation in the Amazon are: i) the conversion of forest into pasture for livestock; ii) cutting and burning to convert forest into crops for family farming; and iii) deployment of grain crops by agro-industry. Of these, the conversion of forests into pasture is predominant (Margulis, 2003). They have also argued that the drastic 
reduction in tax incentives for agricultural enterprises in the late 1980s lead to a reduction in the pace of deforestation, which, however, did not occur. In the 1990s, other factors than the government development projects ${ }^{1}$ became more decisive in the maintenance of deforestation, primarily predatory logging, extensive livestock farming and agrarian reform settlements ${ }^{2}$.

Some projections suggest that deforestation, despite a reduction in its rates between 2004 and 2012, may expand in the coming decades. Soares Filho et al. (2005) estimated that the projected deforestation will eliminate $40 \%$ of the current 5.4 million $\mathrm{km}^{2}$ of forests by 2040 if the occupancy patterns follow the trajectory of the last two decades. Moreover, an increase in deforestation implies a growth of GHG emissions associated with changes in land use. According to Gouvello (2010)'s estimates, the total emissions from land-use changes and forests in Brazil may grow by $25 \%$ by 2030 , reaching an annual rate of 916 thousand tons of $\mathrm{CO}_{2}$ equivalent, which may compromise the target reductions of reducing GHG proposed by the Brazilian government.

The latest deforestation estimates in the Amazon published by INPE (INPE, 2013) showed that from 2012 to 2013, there was an approximate $30 \%$ increase in the deforestation rate, which seems to confirm these previous projections. Although it is the second lowest rate recorded by INPE since the monitoring system began in 1988, it is an indication that deforestation could increase in the future. The prospect of increased deforestation in the Amazon has even more force when considering the adoption of some measures in the New Forest Code $^{3}$, which was approved in May 2012. Included among the points of the New Code is a reduction of the limit of the legal reserve (RL) in the region ${ }^{4}$ and a regularization of the smallholder farmers, excluding them from the obligation of recovering areas that were deforested in permanent preservation areas (APPs.) According to IPEA (2011), the recovery of deforested legal reserves would offset the emissions of 3.15 billion tons of carbon, which would be enough to meet the Brazilian government's four-year target to reduce emissions from deforestation.

This target assumed by the Brazilian government was presented in 2009 at COP $15^{5}$. The proposal was a voluntary reduction in GHG emissions mainly through an 80\% reduction in deforestation by 2020 . Thus, combating deforestation in Brazil has become a priority for the government as well as for the international organizations that are concerned with global warming's effects. According to Fearnside (2005), an effective surveillance and the collection of taxes from those who do not have authorization from the Brazilian Institute of Environment and Renewable Natural Resources (IBAMA) should be accompanied by the necessary understanding of the social, economic and political aspects of the region. Bringing this concern to the economy of the regions in the Amazon, the question arises as to how the control of deforestation can restrict agricultural expansion, which represents an important economic activity in the region. Without alternatives for growth in agriculture and other sectors, which are indirectly affected, there may be a tradeoff between the goals of regional economic growth and the preservation of the forest.

Some options are indicated to reconcile the economic growth of the region with sustainable development and the reduction of deforestation. One refers to intensifying agriculture by increasing land productivity. This increase in productivity would allow the same area, which has been deforested, to produce a greater output amount without expanding the deforested area as crop or pasture land through additional deforestation.

\footnotetext{
${ }^{1}$ The government development projects appear to affect deforestation, mainly in the decades of 1970 and 1980 (Pfaff, 1999).

${ }^{2}$ Land reform policies and violent conflict in the Amazon region can be seen in Alston et al., 2000.

${ }^{3}$ The Brazilian Forest Code was created by Law No. 4771 on September 15, 1965. The Code sets limits on property use, which must coincide with existing vegetation on the ground for the common good of all inhabitants of Brazil. The first Brazilian Forest Code was established by Decree No. 23,793, on January 23, 1934.

${ }^{4}$ The portion to be preserved in the current Forest Code is $80 \%$, but is decreased to $50 \%$ in states that have $65 \%$ of their territory designated as protected areas or indigenous lands.

${ }^{5}$ COP15 (United Nations Conference on Climate Change), held from December 7-18, 2009, in Copenhagen brought together 193 member countries of the United Nations Framework Convention on Climate Change. Its proposal was to define a global action agenda to control global warming and ensure the survival of the human species.
} 
In this context, it is relevant to investigate the aspects of a possible tradeoff between environmental conservation and economic growth in the region. Furthermore, it is important to understand the relationship among agricultural activities with the land occupation and use. The goals of this paper, therefore, are: i) to evaluate the impacts of land-use policies on regional growth in Amazon ${ }^{6}$; ii) to investigate the role of agricultural technical improvement in the region. We built an interregional dynamic computable general equilibrium model (CGE) for 30 regions in the Amazon and the rest of Brazil, called REGIA (Interregional General Equilibrium Model for the Brazilian Amazon) ${ }^{7}$. REGIA has a module of land-use change that enables it to model the conversion of different categories of land use. The incorporation of the land module into REGIA is fundamental in the analysis of the effects of a policy that restricts land use and directly affects the agricultural activity in the region.

Therefore, REGIA was used to simulate a scenario considering the targeted deforestation reduction of $80 \%$ by 2020 in accordance with the National Plan on Climate Change - PNMC (2008), followed by a hypothetical zero deforestation policy from 2021 to 2030 . Moreover, a simulation was performed to estimate the land productivity gains needed to offset the adverse effects of the deforestation policy on the Amazon economy.

\section{METHODOLOGY}

\subsection{REGIA model}

REGIA is a Computable General Equilibrium model (CGE) with a recursive dynamic and landuse module for 30 regions of the Brazilian Legal Amazon ${ }^{8}$ and the rest of Brazil. It is a bottom-up model, that is, a multiregional model where the national results are aggregations of the regional results. Moreover, it is the first CGE model built for the Amazon economy with this very detailed regional disaggregation.

REGIA has some improvements over other CGE models that also examined issues related to the Amazon and deforestation, such as Pattanayak et al. (2009) and Cattaneo (2001). The first improvement is the treatment of land use in a recursive dynamic model so we can analyze the impacts of different scenarios over time as well as the endogenous adjustment of land supply. The second improvement is the largest regional disaggregation - 30 regions of the Amazon and the rest of Brazil.

REGIA has a core theoretical structure similar to the Australian TERM, an acronym for The Enormous Regional Model (Horridge et al., 2005). TERM is a Johansen type bottom-up multi-regional CGE model that is derived from the continued development of the ORANI (Dixon et al., 1982) model and its generic version, the ORANI-G (Horridge, 2000). TERM was developed to address disaggregated regional data and also to allow for the generation of faster solutions for simulations relative to available models (Horridge et al., 2005).

REGIA is composed of blocks of equations that determine relationships between supply and demand, according to optimization assumptions and market-clearing conditions. In addition, several national aggregates are defined in these blocks as the aggregate employment, GDP, balance of trade and price indexes. The most productive sectors minimize production costs subject to a technology of constant returns to scale in which the combinations of intermediate inputs and primary factors (aggregated) are determined by fixed coefficients (Leontief). There is substitution via the prices of domestic and imported goods in the composition of inputs according to the function of the constant elasticity of substitution (CES). A CES specification also controls the allocation of a domestic compound among the various regions. In REGIA, substitution also takes place between capital, labor and land in the composition of the

\footnotetext{
${ }^{6}$ This article is a contribution from the Brazilian Research Network on Global Climate Change, agreement FINEP/RedeCLIMA 01.08.0405.01.

${ }^{7}$ REGIA refers to the aquatic lily pad that is typical of the Amazon region. It has a large leaf-shaped circle, which lies on the surface of the water, and can grow to be up to 2.5 meters in diameter and support up to 40 pounds if well-distributed on its surface.

${ }^{8}$ Throughout the paper we use the word "Amazon" to refer to the "Brazilian Legal Amazon."
} 
primary factors through CES functions; however, the land factor is allocated only in the agriculture and livestock sectors.

The goods of a given region that are directed to another are compounded by the basic values and the trade and transport margins. The share of each margin in the delivery price is a combination of source, destination and goods source (domestic or imported). Margins on goods from one region to another can be produced in different regions. It is expected that margins are distributed more or less equally between the origin and destination or between intermediate regions in the case of transport from more distant regions. In addition, there is substitution between suppliers of margins, according to a CES function.

In the model, there is a representative household for each region consuming domestic and imported goods. The choice between domestic and imported goods (from other countries) is held by a CES (Armington assumption ${ }^{9}$ ) specification. The treatment of household demand is based on a combined system of preferences, CES/Klein-Rubin. Thus, the utility derived from consumption is maximized according to this utility function. The specification gives the linear expenditure system (LES) ${ }^{10}$, in which the share of expenditure above the subsistence level for each good represents a constant proportion of the total subsistence expenditure of each family.

The REGIA model has a recursive dynamic specification. Investment and capital stock follow mechanisms of accumulation and intersectoral shift from pre-established rules related to the depreciation and rates of return. Thus, one of the modifications to make REGIA a dynamic model was to connect the annual investment flows to the capital stocks.

The model does not include a process of temporal labor market adjustment. For the simulations in this paper, which has a time horizon of 25 years, a configuration was adopted where the national aggregated employment in the baseline is exogenous (from 2006 to 2011, adjusted with observed data, and from 2012 is determined by population growth). In the policy scenario, the aggregate national employment is fixed relative to the baseline scenario. This implies an endogenous response of the average wage with the fixed sectoral wage and regional wage differentials. Thus, there is intersectoral and regional labor mobility.

Government consumption is exogenous. The model operates with market equilibrium for all goods, both domestic and imported, as well as the market factors (capital, land and labor) in each region. The purchase prices for each user in each region (producers, investors, households, exporters, and government) are the sum of the basic values, sales taxes (direct and indirect) and margins (trade and transport). Sales taxes are treated as ad valorem taxes on basic flows. Demands for margins (trade and transport) are proportional to the flow of goods to which the margins are connected.

\subsection{The Land Use Module}

One of the advantages of REGIA is the incorporation of a land-use module. Land is one of the primary factors in the model, in addition to capital and labor, and it is an important factor in the production of agricultural sectors. Land use is modeled separately for each region, keeping the total area fixed and divided into four types: i) cropland, ii) pasture, iii) planted forest and iv) natural forest and other areas. In the model, the agricultural sectors/goods, as well as land use, are specific to each region.

It is assumed that each agricultural sector of the model is connected to one of these types of land uses. The area of natural forest and other uses is defined as the total area of each region minus the cropland, pasture and planted forest. That is, it includes all of the areas that are not used in agro-forestry systems, such as natural forests, urban areas, mountains, roads and rivers. These latter areas are thought to change more slowly than natural forests, and therefore, the change (decline) in this type of land use is a proxy for measuring deforestation by the expansion of agriculture or forestry.

\footnotetext{
${ }^{9}$ Armington hypothesis - goods of different origins are treated as imperfect substitutes.

${ }^{10}$ The LES function is suitable for broad aggregates of goods where specific substitutions are not considered. That is, crossprice elasticities are equal to the income effect given in the Slutsky equation without any contribution from the cross-price effects. This implies that all goods have a weak complementarity. The linear expenditure system does not allow the inclusion of inferior goods (that is, negative income elasticities).
} 
Land may be allocated between different agricultural sectors according to the remuneration gap. Thus, the demand for land responds to changes in the land remuneration to each sector. Each land use (cropland, pasture and planted forest) is distributed in year $t$ according to a CET (constant elasticity of transformation) function ${ }^{11}$ between different goods for each region:

$$
x_{i r}=x_{r}+\alpha_{\text {lnd }}\left(p_{\text {ir }}-p_{r}\right)
$$

where $x_{i r}$ is the percentage change in the demand for land allocated to sector $i^{12}$ in region $r ; p_{i r}$ is the percentage change in the land remuneration to sector $i$ in region $r ; x_{r}$ is the percentage change of the total land (cropland, pasture and planted forest) in region $r$; and $p_{r}$ is the average remuneration to all sectors in region $r$. Thus, if in one region the remuneration to sector $i$ is above the average remuneration to the region $\left(p_{i r}-p_{r}>0\right)$, then a positive change in the allocation of land will occur toward sector $i$.

The total change in the demand for each land use for each region is given by $x_{r}=\sum_{k} S_{k} x_{k}$, using the distribution of the remuneration $S_{k}$, with $k$ representing the various land uses. However, we should adopt a physical limit to the total area in region $r$, which will be $\sum_{k} H_{k} x_{k}=0$, using the distribution of land in hectares $H_{k}$. Therefore, to maintain a constant total area, a physical variable in hectares, $n_{k r}$, was used for each land use by region $r$ and computed by:

$$
n_{k r}=x_{k r}+\mu
$$

in which $\mu$ is calculated so that $0=\sum_{k} H_{k} n_{k}$ to guarantee that the total physical supply of land will be fixed. Thus, the demand for land, according to the different uses, is connected to the land supply in the model. The idea is that the demand for land, $x_{k r}$, influences the process of the conversion of land between the uses, that is, the supply side, $n_{k r}$. In the REGIA model, this is operationalized upon determining that the variation of demand for land is equal to the variation of supply for land. This mechanism guarantees the equilibrium in the land market, fixing the total regional land available.

The supply side of land will allow the factor to move between different categories of land between year $t$ and year $t+1$. A CET function could not capture the conversion process between the types of land uses. For this, the conversion process is controlled by a transition matrix representing the conversion possibilities of land between year $t$ and year $t+1$. The matrix represents the mobility of land between uses, indicating the possibilities of the transformation of different types of land.

The transition matrix captures the fact that the most productive land is initially used in the production process, and at the same time, the use of marginal land that could be converted into productive use is limited. The economic process of land conversion is as follows: initially, forests would be converted into areas for pasture, which ultimately could be converted into areas for cropland (Ferreira Filho and Horridge, 2012; Cattaneo, 2002; Macedo et al., 2012; Barona et al., 2010). Therefore, the matrix shows that the conversion between uses, such as cropland and pasture, for example, is more easily performed than that for cropland directly from natural forests. If the difference between the amount of land used in agricultural production and the total area of the region is large, the rise in the demand for land will lead to the greater conversion of land for agricultural uses. This, in turn, will lead to an increase in the remuneration of land to offset the costs associated with this conversion.

The transition matrix was built based on the methodology developed by Ferreira, Filho and Horridge (2014), and calibrated with satellite data from TerraClass ${ }^{13} 2008$ and 2010 (obtained from

\footnotetext{
${ }^{11}$ Within each region, the area of "Cropland', for example, in the current year is predetermined. However, the model allows a given area of "Cropland" to be re-allocated among crops according to a CET rule where CET = 0,5 (Ferreira Filho and Horridge, 2014).

${ }^{12} i=1$ (rice), 2 (maize), 3 (wheat and cereals), 4 (sugar cane), 5 (soybeans), 6 (other crops), 7 (cassava), 8 (tobacco), 9 (upland cotton), 10 (citrus fruits), 11 (coffee beans), 12 (forestry and silviculture), 13 (cattle), 14 (milk and beef), 15 (pigs) 16 (birds) and 17 (eggs). Products 1 to 11 are linked in the model code to the cropland; good 12 is related to the use of planted forests and, finally, products 13 to 17 for pasture use.

13 This article falls under the URBIS Amazonia project that discusses the influences of social and economic factors in the process of urbanization in the Amazon. This project was conducted by a multidisciplinary team led by the INPE, which provided the TerraClass data for the construction of the transition matrix to REGIA. See the following link to published papers of the URBIS Amazônia project: <http://www.dpi.inpe.br/urbisAmazonia/doku.php?id=urbis:producao>
} 
Prodes/INPE) along with data from the Agricultural Census for 1995 and $2006^{14}$ (IBGE) for 30 regions in the Brazilian Amazon. The calibrated matrix indicates how land use changes between different types (cropland, pasture, planted forest and natural forest) over time. Between two periods (years), the model allows land to move between cropland, pasture, planted forest, or natural forest and to be converted into one of the three. The transition matrix ${ }^{15}$ for Amazon are illustrated in Chart 1 . The sum of the lines represents the land use in year 2008, and the sum of the columns represents the land use in year 2010, which are values from TerraClass and the Agricultural Census database. The matrix was built using a biproportional adjustment method, known as RAS ${ }^{16}$, of rows and columns scaling. The off-diagonal elements show the areas of land that have changed between the two periods.

\section{Chart 1 -Transition Matrix for two regions used in the REGIA model (in millions of hectares)}

\begin{tabular}{|lccccc|}
\hline $\begin{array}{c}\text { Conversion } \\
\text { Possibilities }\end{array}$ & Cropland & Pasture & $\begin{array}{l}\text { Planted } \\
\text { Forest }\end{array}$ & $\begin{array}{l}\text { Natural } \\
\text { Forest }\end{array}$ & Total in 2008 \\
\hline Cropland & 5.0 & 0.2 & 0.2 & 0.5 & 5.9 \\
Pasture & 2.3 & 39.5 & 2.0 & 0.6 & 44.5 \\
Planted Forest & 0.2 & 0.9 & 13.7 & 0.2 & 15.0 \\
Natural Forest & 0.8 & 4.3 & 22.1 & 413.5 & 440.8 \\
\hline Total in 2010 & 8.3 & 44.9 & 38.1 & 414.9 & 506.2 \\
\hline
\end{tabular}

Source: Elaborated by the authors according to INPE data.

Chart 1 shows in the first line and column that 5.0 of 5.9 million hectares, which was cropland in 2008, remained as cropland in 2010 according to INPE data. The first column also shows that 2.3 of 44.5 million hectares, which was pasture in 2008, converted to cropland in 2010. The last line shows the transformation of natural forest into other uses, which can be understood as deforestation. For example, 4.3 million of hectares, which was natural forest in 2008, converted to pasture in 2010. And another 22.1 million of hectares was converted from natural forest in 2008 into planted forest in 2010.

The land supply in each category (cropland, pasture, planted forest and natural forest) for each region increases according to the annual percentage growth rate of each use given by the transition matrix:

$$
N \quad k, t+1=100 \times \Delta N_{k,(t+1, t)} / N_{k, t}
$$

In addition to this annual growth rate, to adjust the transition matrix for the next period, the current stock of land in year $t$ is distributed for next year, $t+1$, responding to changes in the remuneration of land. The transition matrix can be expressed as a percentage share (that is, the total sum of lines is equal to 1) showing the probability that a particular hectare of land used for pasture would be used the next year for cropland. In REGIA, these probabilities or proportions are modeled as a function of the variation in the remuneration of each type of land:

\footnotetext{
14 The data used to construct the transition matrix were given by TerraClass. However, because the data source for the sectoral output was from the IBGE, some adjustments had to be made using the Agricultural Census data because some sectors had production according to IBGE data, but did not have output according to data from TerraClass. This adjustment was minimal and represented less than $10 \%$ of the land-use data. The option for TerraClass data is explained by the quality of information from satellite data compared to Census data, which is based on farmers' responses.

15 The transition matrix assumes that natural forests would be initially converted into areas for pasture and that after some time would be able to be converted into areas for crops. We built a transition matrix for the 30 regions in Amazon and for the rest of Brazil.

16 The RAS method is an interactive mechanism that seeks to adjust the values of the rows and columns of a matrix, with its total considering the proportionality of the total values. This method calculates a new set of values for a matrix of cells from a previous structure, causing the sum of the rows and columns to be consistent with the expected total. More information about the RAS method can be found in Miller and Blair (2009).
} 
$S p k r=\mu_{p r} \cdot L_{p k r} \cdot P_{k r}^{\beta_{l n d}} \cdot M_{k r}$

where the subscript $r$ denotes the region. $S_{p k r}$ is the participation of land of the $p$ type that becomes $k$ in region $r . \mu_{p r}$ is an adjustment variable to ensure that $\sum_{k} S_{p k r}=1 . L_{p k r}$ is a constant of calibration that represents the initial value of $S_{p k r}$ (given by the transition matrix). $P_{k r}^{\beta_{l n d}}$ is the average remuneration of land of the type $k . \beta_{\text {lnd }}$ is a sensitivity parameter that measures the response of the supply of land in relation to changes in the remuneration. $M_{k r}$ is a shift variable with an initial value equal to 1 .

The sensitivity parameter, $\beta_{l n d}$, represents the elasticity of land supply and was calculated according to Van Meijl et al. (2006) and Farias (2012). The elasticity of land supply with respect to land price changes should reflect the notion that greater land availability is related to higher values of elasticity. We can see the elasticity by region in Table I. A greater availability of land implies an easier process of land conversion in terms of costs. Thus, if the remuneration of cropland increases in relation to the remuneration of pasture in year $t$ (demand side), the rate of conversion from pasture to cropland will increase, and thus, the amount of land devoted to cropland in $t+1$ also increases. To model the conversion rate of natural forests, it was necessary to consider a fictitious remuneration, in this case, the Final User Price Index. Thus, the transition matrix is adjusted annually as is the supply of land.

Table I -Elasticity of land supply by region in Amazon and the rest of Brazil

\begin{tabular}{lcclcc}
\hline \hline \multicolumn{1}{c}{ Region } & UF & $\begin{array}{c}\text { Elasticity of } \\
\text { land supply }\end{array}$ & \multicolumn{1}{c}{ Region } & UF & $\begin{array}{c}\text { Elasticity of } \\
\text { land supply }\end{array}$ \\
\hline Madeira Guaporé & RO & 1.05 & Norte do Amapá & AP & 1.59 \\
Leste de Rondônia & RO & 0.55 & Sul do Amapá & AP & 1.56 \\
Vale do Juruá & AC & 1.39 & Ocidental de Tocantins & TO & 0.50 \\
Vale do Acre & AC & 0.92 & Oriental de Tocantins & TO & 0.93 \\
Norte do Amazonas & AM & 1.65 & Norte do Maranhão & MA & 0.76 \\
Sudoeste do Amazonas & AM & 1.62 & Oeste do Maranhão & MA & 0.54 \\
Centro do Amazonas & AM & 1.52 & Centro do Maranhão & MA & 0.87 \\
Sul do Amazonas & AM & 1.58 & Leste do Maranhão & MA & 1.27 \\
Norte de Roraima & RR & 1.55 & Sul do Maranhão & MA & 1.15 \\
Sul de Roraima & RR & 1.52 & Norte do Mato Grosso & MT & 0.90 \\
Baixo Amazonas & PA & 1.37 & Nordeste do Mato Grosso & MT & 0.98 \\
Marajó & PA & 1.45 & Sudoeste do Mato Grosso & MT & 0.63 \\
Metropolitana de Belém & PA & 0.30 & Centro-Sul do Mato Grosso & MT & 1.32 \\
Nordeste do Pará & PA & 0.41 & Sudeste do Mato Grosso & MT & 0.70 \\
Sudoeste do Pará & PA & 1.37 & Restante do Brasil & - & 0.32 \\
Sudeste do Pará & PA & 0.56 & & & \\
\hline \hline
\end{tabular}

Source: Elaborated by the authors.

\subsection{The Database}

The database for the REGIA model was constructed through a process of regionalization of a national input-output matrix. The procedure was based on the methodology developed by Horridge (2006) and was adapted for the Brazilian case. Basically, from input-output data for 2005 and a large set of regional data, we estimated an interregional trade matrix using a distance matrix and a gravitational approach. The main hypothesis of the gravitational approach ${ }^{17}$ is that interregional trade is based on the distance between the regions and the interaction derived from the size of its economies.

Details of the procedure for building a database for REGIA are in Carvalho (2014). The result of this procedure is a consistency of the database with the official data of National Accounts, Input-Output

\footnotetext{
${ }^{17}$ A widespread theoretical justification for the idea that bilateral trade flows are positively associated with regional incomes and negatively with the distance between them is based on a trade model developed by Krugman (1980). Further details about the method and some applications can be found in Miller and Blair (2009).
} 
Matrix, IBGE (Brazilian Institute of Geography and Statistics) information, International Trade (SECEX - International Trade Secretary), Industrial Production (IAP) and Employment (RAIS - Annual List of Social Information). One of the most important components of the database for the simulations is the remuneration of land by region in the Amazon. In the model, land remuneration was allocated to the agricultural and livestock sectors. The land remuneration was obtained from the data of the "Expenditure incurred by establishments - from Leasing" of the 2006 Agricultural Census (IBGE) ${ }^{18}$.

Table II presents shares of economic and population data for the 30 Amazon regions in the model and rest of Brazil.

Table II - Shares of Economic and Population Data for the 30 Amazon regions and the rest of Brazil

\begin{tabular}{|c|c|c|c|c|c|c|c|c|c|}
\hline Regions & State & $\begin{array}{l}\text { Share in } \\
\text { the } \\
\text { Brazilian } \\
\text { GDP }(\%)\end{array}$ & $\begin{array}{c}\text { Share in } \\
\text { the } \\
\text { Amazon } \\
\text { GDP }(\%)\end{array}$ & $\begin{array}{c}\text { Share in the } \\
\text { Brazilian } \\
\text { Population } \\
(\%)\end{array}$ & Regions & State & $\begin{array}{l}\text { Share in } \\
\text { the } \\
\text { Brazilian } \\
\text { GDP }(\%)\end{array}$ & $\begin{array}{c}\text { Share in } \\
\text { the } \\
\text { Amazon } \\
\text { GDP }(\%)\end{array}$ & $\begin{array}{c}\text { Share in the } \\
\text { Brazilian } \\
\text { Population } \\
(\%)\end{array}$ \\
\hline Madeira Guaporé & RO & 0.21 & 2.78 & 0.30 & Norte do Amapá & $\mathrm{AP}$ & 0.02 & 0.21 & 0.02 \\
\hline Leste Rondoniense & RO & 0.34 & 4.40 & 0.53 & Sul do Amapá & $\mathrm{AP}$ & 0.21 & 2.67 & 0.30 \\
\hline Vale Juruá & $\mathrm{AC}$ & 0.04 & 0.53 & 0.11 & Ocidental de Tocantins & TO & 0.28 & 3.65 & 0.50 \\
\hline Vale Acre & $\mathrm{AC}$ & 0.16 & 2.12 & 0.26 & Oriental de Tocantins & $\mathrm{TO}$ & 0.15 & 1.93 & 0.26 \\
\hline Norte Amazonense & $\mathrm{AM}$ & 0.02 & 0.20 & 0.06 & Norte Maranhense & MA & 0.60 & 7.76 & 1.21 \\
\hline Sudoeste Amazonense & $\mathrm{AM}$ & 0.05 & 0.61 & 0.19 & Oeste Maranhense & MA & 0.31 & 4.08 & 0.69 \\
\hline Centro Amazonense & $\mathrm{AM}$ & 1.54 & 20.03 & 1.37 & Centro Maranhense & MA & 0.11 & 1.43 & 0.48 \\
\hline Sul Amazonense & $\mathrm{AM}$ & 0.05 & 0.60 & 0.13 & Leste Maranhense & MA & 0.05 & 0.63 & 0.46 \\
\hline Norte de Roraima & $\mathrm{RR}$ & 0.13 & 1.70 & 0.17 & Sul Maranhense & MA & 0.07 & 0.87 & 0.15 \\
\hline Sul de Roraima & $\mathrm{RR}$ & 0.02 & 0.30 & 0.04 & Norte Matogrossense & MT & 0.47 & 6.09 & 0.45 \\
\hline Baixo Amazonas & PA & 0.14 & 1.85 & 0.37 & Nordeste Matogrossense & MT & 0.11 & 1.42 & 0.14 \\
\hline Marajó & PA & 0.04 & 0.53 & 0.23 & $\begin{array}{l}\text { Sudoeste Matogrossense } \\
\text { Centro-Sul }\end{array}$ & MT & 0.13 & 1.66 & 0.16 \\
\hline Metropolitana de Belém & $\mathrm{PA}$ & 0.86 & 11.17 & 1.29 & Matogrossense & MT & 0.46 & 5.96 & 0.55 \\
\hline Nordeste Paraense & PA & 0.18 & 2.37 & 0.89 & Sudeste Matogrossense & MT & 0.32 & 4.09 & 0.22 \\
\hline Sudoeste Paraense & PA & 0.07 & 0.97 & 0.26 & Amazônia Legal & & 7.71 & 100.00 & 12.52 \\
\hline Sudeste Paraense & $\mathrm{PA}$ & 0.57 & 7.41 & 0.75 & Rest of Brazil & & 92.29 & & 87.48 \\
\hline
\end{tabular}

Source: Elaborated by the authors.

\section{CLOSURE AND SIMULATIONS}

\subsection{Model Closure}

Model closure is the determination of sets of endogenous and exogenous variables in simulations. This closure represents hypotheses about the economy and its adjustments to shocks (policies). REGIA is a dynamic model and allows for the accumulation of capital over time as well as adjustments to the land

\footnotetext{
18 The division of this information between livestock and agriculture was taken in accordance with the lease of land values by activity groups. For example, for agriculture, the rental values of the groups were combined, such as the temporary crop output, horticulture and floriculture, permanent crops output, seeds, seedlings and other forms of plant propagation and forestry production. For livestock, the rental values of the groups were also combined, such as livestock and keeping other animals, fisheries and aquaculture. Because the model's database comes from 2005, a deflator was applied to the monetary values of the Agricultural Census to be equal to the input-output matrix. Thus, we obtained the national land remuneration for agriculture and livestock. The last step was to divide the remuneration of land by region, given that the value of it is proportional to the production of agriculture and livestock in each region.
} 
market. The three closures used for the simulations are: i) historical closure, ii) baseline closure and iii) policy closure.

At first, there is a historical closure, from 2006 to 2011 to update macroeconomic variables according to IBGE data. In this case, the main national aggregates are considered to be exogenous, such as real GDP, investment, household consumption, government expenditure, exports and aggregate employment. Thus, other variables, such as the gross rate of return, national wage, government demand, exported volume, national propensity to consume, as well as technological change variable are endogenous. In this case, the model calculates how these variables accommodate the national aggregates. Another assumption is that regional areas for "natural forests and other uses" are exogenous to the deforestation rates from 2006 to 2011 according to INPE data.

At baseline from 2012 to 2030, the macroeconomic variables for the aggregate GDP, household consumption and government expenditure are still exogenous and the regional deforestation rates become endogenous. It is assumed that regional consumption follows the regional income and the government expenditure follows the income of households regionally. Labor moves between regions and activities, driven by real wages changes. The model works with relative prices, and the Consumer Price Index was chosen as a numeraire. "Natural forests and other uses" is exogenous only for regions in the model that do not comprise tropical forests and where the capacity for agricultural expansion through deforestation is small. In REGIA, this group is formed by Sudeste Matogrossense, Centro-Sul Matogrossense, Sul Maranhense, Leste Maranhense, Oriental de Tocantins and the rest of Brazil.

In the policy scenario, each macroeconomic variable is endogenous, with the aggregate national employment set exogenously. That is, aggregate employment is fixed relative to baseline, and labor can move regionally. It is assumed that national consumption follows the GDP with endogenous national propensity to consume. And the national total is distributed between regions in proportion to labor income. The government expenditure follows the income of households regionally and nationally. A restriction is imposed on the national balance of trade that determines its exogenous participation in the national GDP, which does not restrict the possibilities of adjusting to the balance of trade for each region individually.

\subsection{Simulations}

The baseline shows the 3\% per year growth of the national economy for the period from 2012 to 2030 and represents the projection that is compared to the policy scenario ${ }^{19}$. Thus, real GDP, household consumption and government expenditure are expected to grow at 3\% per year, while population growth is set at $1 \%$ per year. In addition to these variables, projections of soybean and cattle exports demand were taken from Nassar (2011) consistent with FAO $(2003)^{20}$ projections. The reason for using projection of exports demand for soybeans and cattle is based on the fact that the export market for these products is considered to be an important determinant of deforestation in the region. Soybean and cattle exports demand were projected to increase by $4.25 \%$ and $2.01 \%$, respectively, representing a total increase of $130 \%$ in soybean exports demand and $49 \%$ in cattle exports demand by 2030 .

The aim of the policy scenario is to represent the deforestation control policy proposed in the PNMC (2008), projecting the impact of an $80 \%$ reduction in deforestation by 2020 and a $100 \%$ reduction from 2021 to 2030, which means achieving zero deforestation in regions of the Brazilian Amazon. In REGIA, the control of deforestation in the Amazon implies limiting the expansion of the land factor for productive uses in agriculture. In general, the restriction on land supply will reduce the possibility of converting natural forest areas into other productive uses, such as cropland, pasture and planted forest. The initial impact of limit land supply is an increase in the remuneration of land with negative economic impacts because of the rise in the production cost of agricultural goods. This will directly decrease the activity level in the agricultural sector and indirectly decrease the activity level in other sectors.

\footnotetext{
${ }^{19}$ For more details on the baseline scenario, see Carvalho (2014).

${ }^{20}$ Brazil is modelled as a small open economy and the shock in the simulation was given in the variable "Export quantity shift".
} 
Moreover, limiting deforestation tend to engender more intense impacts on regions where the economy is based more on agricultural activities.

Another effect induced by the simulation is that a more expensive factor (land) encourages a shift towards other primary factors (capital and labor). Even with the replacement from land to labor and capital, there may be a reduction in employment and investment if the activity effect (declining output) is stronger than the substitution effect (between land, labor and capital). The increase in prices of all goods and the drop in employment levels may have the effect of reducing household consumption. Because the model is interregional, restricting deforestation also reallocates output toward least affected areas. These impacts are consistently designed by REGIA, which takes into account the regional interdependence. This spillover effect of policies is an important feature of regional economies in Brazil.

The reduction in land supply also has an effect on exports. The increase in the domestic prices of goods in all regions makes the exported products relatively more expensive than imported goods. Hence, the most affected regions are those where the economy is primarily aimed at agro-exported activities. In summary, the net effect of the direct and indirect causalities will drive the impact on the activity level of each region, and this effect is determined by the characteristics, as the regional trade integration and production structures.

Finally, the last simulation aims to identify the gains in land productivity that would offset the adverse economic effects of the simulated policy of deforestation in the Amazon. The idea behind this simulation is that economic agents or related public policies may respond to deforestation control by modifying the agricultural techniques and livestock to mitigate the constraints imposed by controlling deforestation.

\section{DISCUSSION AND ANALYSIS OF RESULTS}

\subsection{Regional Macroeconomic Results}

The policy results presented here are reported as the cumulative percentage deviation (2012-2030) relative to the baseline scenario. Table III presents the results for the major macroeconomic indicators by region. In general, the impact of the policy to control deforestation does not seem to be excessive. The six regions with major negative impacts on GDP were Norte Matogrossense (-3.6\%), Nordeste Matogrossense (-3\%), Sudoeste Matogrossense (-2.1\%), Marajó, Baixo Amazonas and Leste Rondoniense (approximately - 1.7\% each). Considering the Norte Matogrossense, for example, the interpretation of these results is that this region would attain a cumulative growth $3.6 \%$ lower than that obtained in a scenario without the policy (the baseline scenario).

This greater impact on the Norte and Nordeste Matogrossense is explained in part because these regions have the highest shares of land remuneration on GDP of the entire Amazon. Moreover, agriculture accounts for over $50 \%$ of the total production in these regions. The decline in GDP in Norte Matogrossense is a significant result because it is one of the largest regions in the Amazon and is especially important in soybean and cattle production - two sectors directly affected by the policy. The Sudeste Matogrossense, Baixo Amazonas and Leste Rondoniense regions are economies based on agricultural activities, which represents over $50 \%$ of the total production in each of them, explaining the negative impact.

The silviculture and forestry activity accounts for more than $50 \%$ of all of the production in Marajo, with another $30 \%$ distributed among agriculture sectors. This high share of agricultural production and forestry makes this region one of the most affected by the policy. Also noteworthy is that the decline in investment and household consumption were major drivers of the decrease in GDP in these regions. The Leste Rondoniense also suffered a greater decline in GDP, which is a significant result because the region is an important producer of cattle, accounting for over $13 \%$ of cattle in the Amazon.

As expected, the regions that would be less affected by the policy are those that do not have areas of natural forests to be converted into productive use. Some of these regions, such as Sul Maranhense, Sudeste Matogrossense, Oriental de Tocantins and the rest of Brazil, even present a small gain in GDP $(0.35 \%, 0.20 \%, 0.12 \%$ and $0.06 \%$, respectively). This result can be explained by the dynamics of the 
labor and capital market. Employment will increase in regions less affected by the policy, which will then lead to lower cost increases. Thus, these regions showed small gains in GDP due to interregional migration causing a drop in real wages that then benefits the other regions.

Table III - Simulated Impacts of Controlling Deforestation from 2012 to 2030 - accumulated deviation relative to Baseline (in \% change)

\begin{tabular}{|c|c|c|c|c|c|c|c|c|}
\hline Regions & State & $\begin{array}{c}\text { Regional } \\
\text { GDP }\end{array}$ & $\begin{array}{c}\text { Household } \\
\text { Consumption }\end{array}$ & $\begin{array}{l}\text { Government } \\
\text { Expenditure }\end{array}$ & Investment & Employment & Exports & Imports \\
\hline Madeira-Guaporé & RO & -1.12 & -1.08 & -1.08 & -1.82 & -1.10 & -0.19 & -0.92 \\
\hline Leste Rondoniense & RO & -1.69 & -1.58 & -1.58 & -2.71 & -1.61 & -0.23 & -1.24 \\
\hline Vale do Juruá & $\mathrm{AC}$ & -1.25 & -1.13 & -1.13 & -1.86 & -1.16 & -0.07 & -1.13 \\
\hline Vale do Acre & $\mathrm{AC}$ & -1.37 & -1.27 & -1.27 & -2.08 & -1.29 & -0.10 & -1.25 \\
\hline Norte Amazonense & $\mathrm{AM}$ & -1.66 & -1.12 & -1.12 & -2.15 & -1.14 & 0.01 & -1.53 \\
\hline Sudoeste Amazonense & $\mathrm{AM}$ & -1.46 & -1.26 & -1.26 & -2.00 & -1.28 & 0.04 & -0.98 \\
\hline Centro Amazonense & $\mathrm{AM}$ & -0.72 & -0.73 & -0.73 & -1.26 & -0.75 & -0.25 & -0.62 \\
\hline Sul Amazonense & $\mathrm{AM}$ & -0.80 & -0.73 & -0.73 & -1.26 & -0.75 & 0.04 & -0.42 \\
\hline Norte de Roraima & RR & -1.02 & -0.98 & -0.98 & -1.65 & -1.01 & -0.08 & -1.04 \\
\hline Sul de Roraima & $\mathrm{RR}$ & -0.61 & -0.58 & -0.58 & -1.04 & -0.60 & -0.04 & -0.57 \\
\hline Baixo Amazonas & PA & -1.66 & -1.44 & -1.44 & -2.10 & -1.46 & -0.36 & -1.16 \\
\hline Marajo & PA & -1.70 & -1.22 & -1.22 & -1.90 & -1.25 & -0.01 & -0.94 \\
\hline Metropolitana de Belém & PA & -0.66 & -0.65 & -0.65 & -1.19 & -0.67 & -0.25 & -0.65 \\
\hline Nordeste Paraense & PA & -0.86 & -0.62 & -0.62 & -1.73 & -0.64 & -0.15 & -0.81 \\
\hline Sudoeste Paraense & PA & -0.62 & -0.52 & -0.52 & -1.12 & -0.54 & -0.12 & -0.45 \\
\hline Sudeste Paraense & PA & -0.65 & -0.58 & -0.58 & -1.06 & -0.60 & -0.25 & -0.48 \\
\hline Norte do Amapá & $\mathrm{AP}$ & -0.66 & -0.58 & -0.58 & -1.10 & -0.61 & -0.06 & -0.64 \\
\hline Sul do Amapá & $\mathrm{AP}$ & -0.84 & -0.83 & -0.83 & -1.38 & -0.85 & -0.11 & -0.84 \\
\hline Ocidental do Tocantins & TO & -0.05 & -0.04 & -0.04 & -0.11 & -0.06 & -0.09 & -0.02 \\
\hline Oriental do Tocantins & TO & 0.06 & 0.09 & 0.09 & -0.06 & 0.06 & -0.07 & 0.05 \\
\hline Norte Maranhense & MA & -0.69 & -0.65 & -0.65 & -1.11 & -0.67 & -0.26 & -0.71 \\
\hline Oeste Maranhense & MA & -1.09 & -0.93 & -0.93 & -1.63 & -0.95 & -0.28 & -0.80 \\
\hline Centro Maranhense & MA & -1.38 & -1.08 & -1.08 & -1.95 & -1.10 & -0.29 & -0.96 \\
\hline Leste Maranhense & MA & -0.23 & -0.22 & -0.22 & -0.59 & -0.24 & -0.23 & -0.29 \\
\hline Sul Maranhense & MA & 0.28 & 0.32 & 0.32 & 0.09 & 0.30 & -0.15 & 0.11 \\
\hline Norte Mato-Grossense & MT & -3.56 & -3.04 & -3.04 & -4.46 & -3.06 & -0.34 & -2.30 \\
\hline Nordeste Mato-Grossense & MT & -2.96 & -2.49 & -2.49 & -3.62 & -2.51 & -0.39 & -2.08 \\
\hline Sudoeste Mato-Grossense & MT & -2.14 & -1.94 & -1.94 & -3.26 & -1.96 & -0.33 & -1.39 \\
\hline Centro-Sul Mato-Grossense & MT & -0.96 & -1.00 & -1.00 & -1.66 & -1.03 & -0.21 & -0.97 \\
\hline Sudeste Mato-Grossense & MT & 0.14 & 0.17 & 0.17 & -0.03 & 0.14 & -0.15 & 0.15 \\
\hline Rest of Brazil & - & 0.06 & 0.11 & 0.11 & 0.01 & 0.09 & -0.11 & 0.05 \\
\hline Legal Amazon & - & -1.06 & $-0,91$ & $-0,93$ & $-1,55$ & $-0,98$ & $-0,20$ & $-0,82$ \\
\hline
\end{tabular}

Source: Elaborated by the authors based on simulation results from the REGIA model

This simulated policy represents a direct increase in the costs of agricultural production - the main economic activity of most regions in the Amazon also reduces exports. The increase in the production costs that is passed on to the final prices of goods makes local production relatively more expensive than the imported goods and discourages exports. Likewise, the effect of the drop in activity also reduces imports. As the regions cannot convert more land into productive use, they seek to replace the land factor with labor and capital. This suppresses the investment/capital ratio, promoting a decline in investment due to low rates of return. Employment also decreases, which suggests that the activity effect (decrease in GDP) is greater than the substitution effect (among the primary factors). The fall in employment leads to a consequent reduction in household income and consumption, which is an indication that the policy causes a loss of welfare.

\subsection{Sectoral Results}

The policy, as it restricts the possibilities of converting forests into productive agricultural use, has a negative impact mainly on the agricultural sectors. Soybean production is important in the Amazon and accounts for approximately $35 \%$ of national soybean production. Of all of the soybeans produced in the 
Amazon, nearly $60 \%$ are from the Norte Matogrossense, followed by Sudeste and Nordeste Matogrossense, which together produce over $25 \%$ of the total soybeans. Soybean production is considered to be one of the main drivers of deforestation, so the negative impact was expected. Figure 1 shows the impact of the policy on the soybean and cattle sectors.
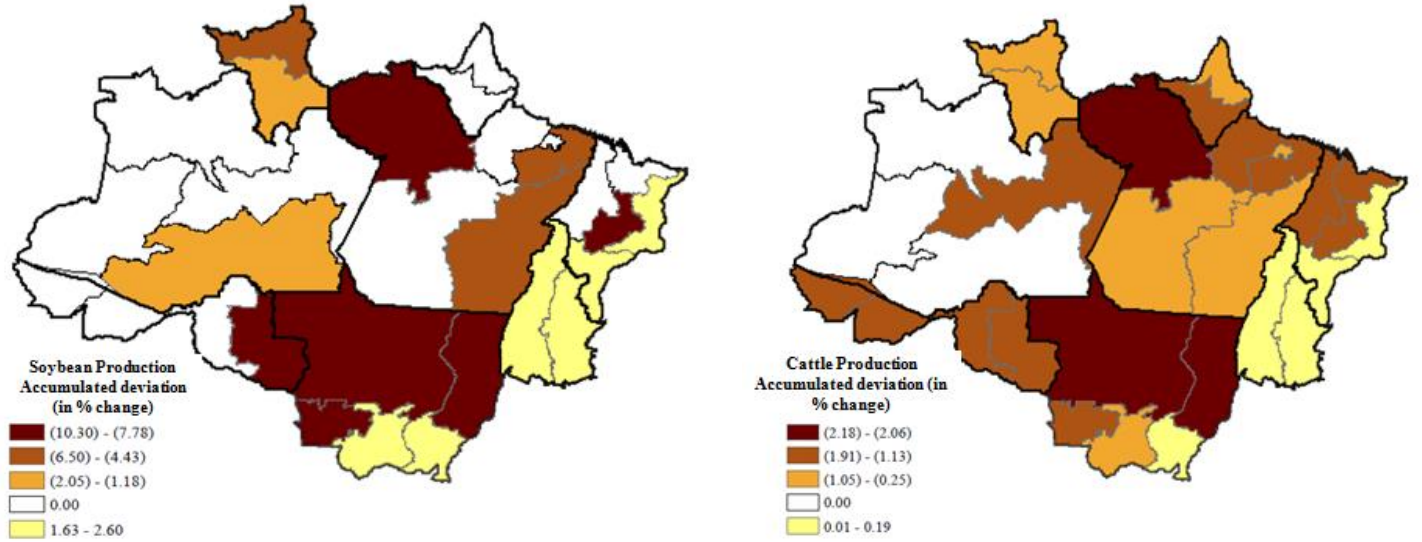

Figure 1 - Percent Change in Soybean and Cattle Production resulting from the Policy to Control Deforestation (accumulated deviation from 2012 to 2030 relative to baseline)

Source: Elaborated by the authors based on simulation results from the REGIA model

We note in Figure 1 that the number of regions in the database that present no impact are not soybean producers or the soybean production is virtually zero. Both the Norte and Nordeste Matogrossense are among the regions most affected by the policy. As expected, the Sudeste Matogrossense would benefit from the policy because it lies outside its scope. In general, production costs increase more in regions that are targets of the policy to control deforestation. This implies that in regions where there are greater production costs impacts ${ }^{21}$, the drop in activity level will be greater as well. In particular, soybean production is the sector with the greatest variations in production costs (one of the most modern agriculture production in Brazil).

Cattle production, one of the main drivers of deforestation, is also an important sector in the Amazon and accounts for almost $30 \%$ of national production. Its production is concentrated in Leste Rondoniense, Sudeste Paraense, Norte and Sudoeste Matogrossense. We can observe from Figure 2 that the regions where cattle production is concentrated are among the most adversely affected by the policy. Cattle activity is also considered to be an important driver of deforestation in the region but shows lower cost increases than soybeans. This is because the remuneration of land in pasture areas is significantly lower than in croplands in the Amazon.

Table VI presents the sectoral results with an aggregation of the 27 sectors into 6 major industries. Because of the free movement of goods and factors within the Brazilian economy, the region "rest of Brazil" shows a positive impact in all industries. However, regions as Centro-Sul Matogrossense, Sul and Leste Maranhense, Oriental and Ocidental of Tocantins, even if they do not have areas of natural forests to be converted into productive use, presented a decline in production of many industries. This is because of the strong commercial relationship between regions inside Amazon. And because of the linkage between the sectors, Industries, Services and Public Administration Sectors present also a decline in its production, even if they are not affected directly by the restriction of land. In general, the results suggest that the largest sectoral negative impact occurs mainly on important agricultural regions such as Norte, Nordeste and Sudeste Matogrossense, and Leste Rondoniense and on regions dominated by small family farms such as Vale Acre and Baixo Amazonas.

\footnotetext{
${ }^{21}$ A table with the costs variation for soybean and cattle can be seen at the Appendix.
} 
Table IV - Percent Change in Production by Sector resulting from the Policy to Control Deforestation (accumulated deviation from 2012 to 2030 relative to baseline)

\begin{tabular}{|c|c|c|c|c|c|c|c|}
\hline Region & State & Agriculture & Livestock & Silviculture & Industries & Services & Public \\
\hline Madeira Guaporé & RO & -1.12 & -0.90 & -2.12 & -0.49 & -1.21 & -1.10 \\
\hline Leste Rondoniense & RO & -2.95 & -1.23 & -2.69 & -0.68 & -1.60 & -1.53 \\
\hline Vale Juruá & $\mathrm{AC}$ & -1.42 & -1.11 & -2.56 & -0.75 & -1.15 & -1.14 \\
\hline Vale Acre & $\mathrm{AC}$ & -1.61 & -1.29 & -3.78 & -0.72 & -1.18 & -1.21 \\
\hline Norte Amazonense & $\mathrm{AM}$ & -1.28 & -0.46 & -2.56 & 0.00 & 0.00 & -0.82 \\
\hline Sudoeste Amazonense & $\mathrm{AM}$ & -1.37 & -0.56 & -3.01 & -0.86 & -1.20 & -1.19 \\
\hline Centro Amazonense & $\mathrm{AM}$ & -1.58 & -0.44 & -2.62 & -0.55 & -0.81 & -0.76 \\
\hline Sul Amazonense & $\mathrm{AM}$ & -0.74 & -0.36 & -0.82 & -0.28 & -1.00 & -0.98 \\
\hline Norte de Roraima & RR & -1.89 & -0.90 & -1.46 & -0.49 & -0.84 & -0.98 \\
\hline Sul de Roraima & $\mathrm{RR}$ & -0.51 & -0.56 & -0.64 & -0.43 & -0.64 & -0.92 \\
\hline Baixo Amazonas & PA & -2.41 & -1.39 & -2.57 & -0.59 & -1.18 & -1.17 \\
\hline Marajó & PA & -1.36 & -0.95 & -2.43 & -0.34 & -1.12 & -0.90 \\
\hline Metropolitana de Belém & PA & -0.80 & -0.53 & 0.25 & -0.44 & -0.67 & -0.65 \\
\hline Nordeste Paraense & PA & -1.09 & -0.90 & -0.17 & -0.53 & -0.82 & -0.64 \\
\hline Sudoeste Paraense & PA & -0.69 & -0.47 & -0.55 & -0.58 & -0.83 & -0.71 \\
\hline Sudeste Paraense & PA & -1.83 & -0.61 & -0.49 & -0.46 & -0.59 & -0.60 \\
\hline Norte do Amapá & $\mathrm{AP}$ & -0.93 & -0.88 & -1.43 & -0.32 & -0.49 & -0.77 \\
\hline Sul do Amapá & $\mathrm{AP}$ & -1.22 & -1.22 & -2.39 & -0.47 & -0.80 & -0.83 \\
\hline Ocidental de Tocantins & TO & 0.28 & 0.00 & 0.84 & -0.13 & -0.27 & -0.17 \\
\hline Oriental de Tocantins & TO & 1.28 & 0.05 & 0.96 & 0.02 & -0.14 & -0.05 \\
\hline Norte Maranhense & MA & -0.84 & -0.91 & -4.67 & -0.51 & -0.60 & -0.66 \\
\hline Oeste Maranhense & MA & -1.91 & -0.81 & -2.95 & -0.56 & -0.82 & -0.82 \\
\hline Centro Maranhense & MA & -3.10 & -0.77 & -2.64 & -0.62 & -0.79 & -0.79 \\
\hline Leste Maranhense & MA & 0.48 & -0.14 & 0.50 & -0.44 & -0.57 & -0.43 \\
\hline Sul Maranhense & MA & 0.97 & -0.12 & 0.52 & -0.15 & -0.07 & -0.49 \\
\hline Norte Matogrossense & MT & -3.75 & -1.76 & -3.77 & -1.42 & -2.45 & -2.30 \\
\hline Nordeste Matogrossense & MT & -3.17 & -1.73 & -3.94 & -1.55 & -1.62 & -1.44 \\
\hline Sudoeste Matogrossense & MT & -5.34 & -1.45 & -4.21 & -1.53 & -2.05 & -1.73 \\
\hline Centro-Sul Matogrossense & MT & 0.22 & -0.35 & 0.70 & -0.70 & -1.08 & -1.15 \\
\hline Sudeste Matogrossense & MT & 0.35 & 0.01 & 0.97 & -0.28 & -0.33 & -0.58 \\
\hline Restante do Brasil & - & 0.19 & 0.10 & 0.95 & 0.02 & 0.02 & 0.09 \\
\hline Amazônia Legal & - & -1.59 & -0.81 & -1.49 & -0.61 & -0.82 & -0.91 \\
\hline
\end{tabular}

Source: Elaborated by the authors based on simulation results from the REGIA model

\subsection{Land-Use Results}

Figure 2 shows the projection of land use in the Amazon in the policy to control deforestation scenario. Given the reduction goal (limiting the land use), aggregate deforestation in the Amazon would decline over time which means an avoided deforestation relative to the baseline. This can be seen in the upward trend in the natural forest area, which is projected to increase to 14.56 million hectares in 2030 relative to the baseline scenario. Because the total area of the region is fixed, the growth of a particular land use must be accompanied by a reduction in another land use. Thus, we note that reducing deforestation is only possible by the reduction of cropland, pasture and planted forest relative to the baseline. In this instance, a reduction in these areas means that in the economic growth scenario (baseline) there would be less conversion of natural forests (deforestation) into these areas.

Because land conversion as established in the REGIA assumes that areas of natural forest are first converted into pasture, pasture areas would suffer the greatest reductions because of the limited growth of land supply. Therefore, these areas would decrease by approximately nine million hectares compared to the baseline scenario. Then, the crop areas and planted forest areas would present a decline in response to the deforestation control policy. The first would have a reduction in area of about four million hectares, while the planted forest areas would be reduced by about two million hectares in 2012-2030 relative to the baseline scenario of economic growth. 


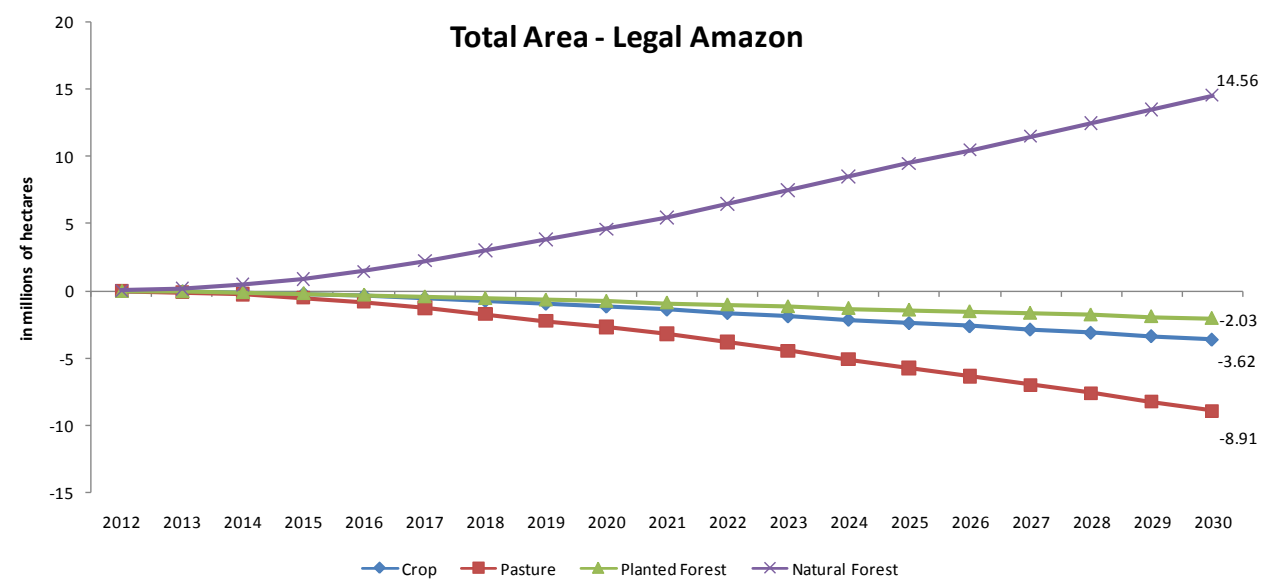

Figure 2 - Land-Use projection as a result of the policy to control deforestation in the Amazon (deviation relative to the Baseline Scenario)

Source: Elaborated by the authors based on simulation results from the REGIA model

Table V presents the results for different types of land use (in millions of hectares) by region. The policy increases the amount of land allocated for natural forest. Furthermore, we can note that the Norte Matogrossense and Sudeste Paraense would be the regions with the largest preserved areas (in hectares). Regarding the crop area, the regions with the greatest reductions in hectares would be Nordeste Matogrossense, Nordeste Paraense, Baixo Amazonas and Vale do Acre. These regions have agricultural goods/sectors in common as the most important activities in their production structures. In these regions, the policy to control deforestation would cause a more severe drop in agricultural production, explaining the greatest reduction in cropland.

Table V - Change in cropland, pasture, planted Forest and Natural Forest Areas (in millions of hectares) in the Policy Scenario - accumulated from 2012 to 2030

\begin{tabular}{|c|c|c|c|c|c|c|c|c|c|c|c|}
\hline \multirow[t]{2}{*}{ Regions } & \multirow[t]{2}{*}{ State } & Crops & Pasture & $\begin{array}{l}\text { Planted } \\
\text { Forest }\end{array}$ & $\begin{array}{l}\text { Natural } \\
\text { Forest }\end{array}$ & \multirow[t]{2}{*}{ Regions } & \multirow[t]{2}{*}{ State } & Crops & Pasture & $\begin{array}{l}\text { Planted } \\
\text { Forest }\end{array}$ & $\begin{array}{l}\text { Natural } \\
\text { Forest }\end{array}$ \\
\hline & & \multicolumn{4}{|c|}{ in millions of hectares } & & & \multicolumn{4}{|c|}{ in millions of hectares } \\
\hline Madeira-Guaporé & RO & -0.03 & -0.52 & -0.06 & 0.61 & Norte do Amapá & $\mathrm{AP}$ & -0.02 & -0.01 & 0.00 & 0.03 \\
\hline Leste Rondoniense & RO & -0.08 & -0.77 & -0.07 & 0.92 & Sul do Amapá & $\mathrm{AP}$ & -0.04 & -0.02 & -0.01 & 0.07 \\
\hline Vale do Juruá & $\mathrm{AC}$ & -0.11 & -0.06 & -0.03 & 0.20 & Ocidental do Tocantins & TO & 0.01 & -0.01 & 0.00 & 0.00 \\
\hline Vale do Acre & $\mathrm{AC}$ & -0.20 & -0.34 & -0.03 & 0.57 & Oriental do Tocantins & TO & 0.00 & 0.00 & 0.00 & 0.00 \\
\hline Norte Amazonense & $\mathrm{AM}$ & -0.02 & 0.00 & -0.02 & 0.04 & Norte Maranhense & MA & -0.18 & -0.10 & -0.04 & 0.33 \\
\hline Sudoeste Amazonense & $\mathrm{AM}$ & -0.09 & -0.02 & -0.03 & 0.15 & Oeste Maranhense & MA & -0.06 & -0.50 & -0.07 & 0.62 \\
\hline Centro Amazonense & $\mathrm{AM}$ & -0.19 & -0.12 & -0.13 & 0.44 & Centro Maranhense & MA & -0.07 & -0.31 & -0.07 & 0.45 \\
\hline Sul Amazonense & $\mathrm{AM}$ & -0.03 & -0.16 & -0.04 & 0.24 & Leste Maranhense & MA & 0.00 & 0.00 & 0.00 & 0.00 \\
\hline \multirow{2}{*}{$\begin{array}{l}\text { Norte de Roraima } \\
\text { Sul de Roraima }\end{array}$} & RR & -0.03 & -0.05 & -0.01 & 0.09 & Sul Maranhense & MA & 0.00 & 0.00 & 0.00 & 0.00 \\
\hline & RR & -0.01 & -0.08 & -0.02 & 0.11 & \multirow{5}{*}{$\begin{array}{l}\text { Norte Mato-Grossense } \\
\text { Nordeste Mato-Grossense } \\
\text { Sudoeste Mato-Grossense } \\
\text { Centro-Sul Mato- }\end{array}$} & MT & -1.27 & -2.10 & -0.21 & 3.58 \\
\hline Baixo Amazonas & PA & -0.38 & -0.32 & -0.22 & 0.92 & & MT & -0.27 & -0.79 & -0.06 & 1.12 \\
\hline Marajo & PA & -0.12 & -0.02 & -0.06 & 0.20 & & MT & -0.08 & -0.40 & -0.03 & 0.51 \\
\hline Metropolitana de & & & & & & & & & & & \\
\hline Belém & PA & -0.01 & -0.01 & -0.01 & 0.03 & & MT & 0.00 & 0.00 & 0.00 & 0.00 \\
\hline Nordeste Paraense & PA & -0.21 & -0.18 & -0.16 & 0.55 & Sudeste Mato-Grossense & MT & 0.00 & 0.00 & 0.00 & 0.00 \\
\hline Sudoeste Paraense & PA & -0.06 & -0.58 & -0.20 & 0.84 & & & & & & \\
\hline Sudeste Paraense & PA & -0.06 & -1.44 & -0.46 & 1.96 & & & & & & \\
\hline
\end{tabular}

Source: Elaborated by the authors based on simulation results from the REGIA model

The pasture area in millions of hectares would be reduced more than the cropland area in most of the Amazon regions. The explanation for this greater reduction in pasture lies in the fact that the model assumes that the conversion of forest areas first occurs towards the pasture area. As such, the Sudeste and Sudoeste Paraense, Norte and Nordeste Matogrossense, and Leste Rondoniense would have the largest reductions in pasture area. This result is explained by the productive structure of these regions, which are 
important producers of cattle in the Amazon. In general, we observe that regions with more natural forest areas would be most affected by the policy to control deforestation and would show greater variation (decline) in its areas for productive use as well as a greater increase in production costs.

In terms of planted forest areas, it can be seen in Table IV that the reduction in these areas is of less magnitude than it is for other uses. This result indicates that the increase in production costs for this type of land is relatively smaller than for the others. However, we can highlight the reduction in planted forest area in Sudeste Paraense and Baixo Amazonas. The Sudeste Paraense is the largest forestry producer in the Amazon, and Baixo Amazonas also has a concentrated production in this sector.

\subsection{Land productivity response to policy}

In the simulations with the REGIA model, we have assumed that the policy to control deforestation occurs during the period from 2012 to 2030. Thus, this section aim to show how land productivity would have to increase in the same period to offset the impacts on regional outputs caused by the limited supply of land. In the baseline scenario, it is assumed that the productivity of land increases by $1 \%$ per year from 2012 to 2030 . There is also an increase in the overall productivity of the primary factors of $0.7 \%$ per year in the same period. Therefore, the results reported in this section should be understood as an additional increase in productivity considering the baseline scenario. Table VI presents the regional results of the rise in productivity for the main agricultural sectors in the REGIA model that would offset the negative impacts in the regions due to the deforestation policy.

Table VI - Results pertaining to the increase in land productivity - accumulated deviation relative to the Baseline Scenario from 2012 to 2030 (in annual \% change)

\begin{tabular}{|c|c|c|c|c|c|c|}
\hline Region & State & Soybeans & Cassava & Corn & $\begin{array}{l}\text { Silviculture and } \\
\text { Forestry }\end{array}$ & Cattle \\
\hline Madeira Guaporé & RO & - & 1.14 & 1.20 & 1.13 & 0.95 \\
\hline Leste Rondoniense & RO & 0.93 & 0.92 & 0.93 & 0.95 & 0.66 \\
\hline Vale Juruá & $\mathrm{AC}$ & - & 1.24 & 1.27 & 1.30 & 1.28 \\
\hline Vale Acre & $\mathrm{AC}$ & - & 1.14 & 1.16 & 1.30 & 1.12 \\
\hline Norte Amazonense & $\mathrm{AM}$ & - & 1.27 & - & 1.28 & - \\
\hline Sudoeste Amazonense & $\mathrm{AM}$ & - & 1.35 & 1.39 & 1.38 & - \\
\hline Centro Amazonense & $\mathrm{AM}$ & - & 1.29 & 1.32 & 1.25 & 1.28 \\
\hline Sul Amazonense & $\mathrm{AM}$ & 1.05 & 1.00 & 1.05 & 0.95 & - \\
\hline Norte de Roraima & RR & 1.13 & 1.11 & 1.13 & 1.09 & 0.99 \\
\hline Sul de Roraima & $\mathrm{RR}$ & 0.89 & 0.83 & 0.89 & 0.83 & 0.75 \\
\hline Baixo Amazonas & PA & 1.29 & 1.27 & 1.29 & 1.25 & 1.26 \\
\hline Marajó & PA & - & 1.12 & - & 1.26 & 1.26 \\
\hline Metropolitana de Belém & PA & - & 0.24 & - & 0.36 & 0.32 \\
\hline Nordeste Paraense & PA & 0.51 & 0.50 & 0.51 & 0.61 & 0.54 \\
\hline Sudoeste Paraense & PA & - & 0.91 & 0.96 & 0.84 & 0.78 \\
\hline Sudeste Paraense & PA & 0.90 & 0.89 & 0.90 & 0.70 & 0.56 \\
\hline Norte do Amapá & $\mathrm{AP}$ & - & 0.97 & - & 1.05 & 1.03 \\
\hline Sul do Amapá & $\mathrm{AP}$ & - & 1.15 & - & 1.17 & 1.17 \\
\hline Ocidental de Tocantins & TO & 0.00 & -0.01 & 0.00 & 0.00 & 0.00 \\
\hline Oriental de Tocantins & TO & 0.00 & -0.01 & 0.00 & 0.00 & 0.00 \\
\hline Norte Maranhense & MA & - & 0.80 & 0.85 & 1.17 & 1.02 \\
\hline Oeste Maranhense & MA & - & 0.92 & 0.93 & 0.88 & 0.65 \\
\hline Centro Maranhense & MA & 1.25 & 1.24 & 1.25 & 1.18 & 1.01 \\
\hline Leste Maranhense & MA & 0.01 & -0.01 & 0.01 & -0.01 & -0.02 \\
\hline Sul Maranhense & MA & 0.00 & -0.01 & 0.00 & 0.00 & -0.01 \\
\hline Norte Matogrossense & MT & 1.11 & 1.09 & 1.11 & 1.30 & 1.10 \\
\hline Nordeste Matogrossense & MT & 1.21 & 1.19 & 1.21 & 1.27 & 1.10 \\
\hline Sudoeste Matogrossense & MT & 0.97 & 0.96 & 0.97 & 1.04 & 0.76 \\
\hline Centro-Sul Matogrossense & MT & 0.00 & -0.01 & 0.00 & 0.00 & 0.00 \\
\hline Sudeste Matogrossense & MT & 0.00 & -0.01 & 0.00 & 0.00 & 0.00 \\
\hline
\end{tabular}

Source: Elaborated by the authors based on simulations results from the REGIA model

We notice, on average, that the annual productivity of the land should grow at approximately $1 \%$ per year so that the policy to control deforestation would not cause any negative impact on production. According Gasques et al. (2008), the productivity of land in Brazil grew by $3.26 \%$ per year from 2000 to 
2005, which suggests that this rate would be possible even in the Amazon. For example, to achieve the given results, the land productivity gains would have to be $0.5 \%$ to $1.4 \%$ per year compared to the baseline scenario to neutralize the effect of controlling deforestation. This would correspond to an increase in productivity of approximately $2.2 \%$ to $3.1 \%$ per year, including the increased productivity per year in the baseline scenario.

\section{CONCLUSIONS}

The main goal of this paper was to analyze the dynamics of land use and impacts of a policy to control deforestation, seeking to contribute to an analysis of different scenarios in the Amazon. For this, we built an interregional dynamic Computable General Equilibrium (CGE) model called REGIA, which incorporates a model of land use known as ILUC (indirect land-use change).

First, a baseline scenario was built to project economic growth by region in a business-as-usual situation without a policy to control deforestation. In this scenario, the Amazon regions are stimulated by the growth of the national economy and the increasing demand to export soybeans and cattle. Related to this scenario, we simulated a policy to control deforestation that aims to reduce deforestation by $80 \%$ by 2020 , followed by a reduction target of $100 \%$ for the period from 2021 to 2030 . The increase in land productivity required to offset the negative impacts of the deforestation control policy was also projected. Overall, the results indicated that the regions most affected by the policy follow two distinct patterns: i) regions in the deforestation arc in Mato Grosso and Rondonia and ii) regions outside the arc that have a smaller share in the total GDP of the Amazon, in Amazonas and Para. According to the data and mechanisms of the model, the former are more negatively affected by having a higher remuneration of land and being more productive. Thus restricting the supply of land would generate higher losses of production per hectare. The regions outside of the arc have lower productivity, and often the growth of their production is linked to the expansion of land (low remuneration), which then leads to the greater negative impact in these regions.

However, in general, the results showed that the costs of a policy to control deforestation in the Amazon are relatively small, although its distribution is heterogeneous between regions, particularly affecting the regions that are most dependent on agriculture and have low productivity. It was also observed that the agriculture intensification in the Amazon can be considered to be a viable alternative for the maintenance of the production, employment, income and consumption in the region.

The results from simulated land productivity response suggest that the required annual gain would be approximately $1.4 \%$ for cropland, $1.3 \%$ for pasture and $1.4 \%$ for planted forest. These results are in addition to the increase in productivity for the land factor and the primary factors that is considered in the baseline scenario, which is approximately $1.7 \%$ per year. The Amazon has a large cleared area that is underutilized (IMAZON, 2013), and the productivity of land in Brazil grew by $3.26 \%$ per year, on average, from 2000 to 2005 (GASQUES et al., 2008). Thus, the results of productivity gains found with the REGIA model seem feasible and could be achieved through incentive policies targeting primary crops and livestock in each region.

According to other studies on this theme, the increased land productivity alone does not seem to hold the expansion of crop areas. The increase in productivity can generate an incentive for producers to add cultivated areas for further expansion of production. Thus, there must be a policy to control deforestation coupled with increasing land productivity. Thus, the government should exercise greater surveillance to curb illegal deforestation and, at the same time, promote economic incentives toward forest conservation. These incentives can be provided with forest concessions for sustainable forest management, payment for environmental services that highlight the payments of REDDs or even the promotion of programs aimed to increase the productivity of deforested land in the Amazon.

A limitation of the methodology employed in this paper is that the issue of proximity between regions has no role in the expansion of agricultural crops or livestock. The model only allows for the expansion of crops in regions where this production already exists in the database, and largely, only the economic conditions of the region influence its expansion. That is, the model does not work properly with 
the issue of expansion of the agricultural frontier, but with the local expansion of activities influenced by competitive market mechanisms. This is also due to the choice of the regional disaggregation of the model.

\section{REFERENCES}

ALENCAR, A. et al. Desmatamento na Amazônia: indo além da emergência crônica. Manaus, Instituto de Pesquisa Ambiental da Amazônia (Ipam), pp.89, 2004.

ALSTON, L. J.; LIBECAP, G. C.; MULLER, B. Land Reform Policies, the Sources of Violent Conflict, and Implications for Deforestation in the Brazilian Amazon. Journal of Environmental Economics and Management, vol. 39, p. 162-188, 2000.

ARIMA, E.; VERÍSSIMO, A. Brasil em Ação: Ameaças e Oportunidades Econômicas na Fronteira Amazônica. Série Amazônia no 19, Belém: Imazon, 2002.

ASSUNÇÃO, J. et al. Deforestation Slowdown in the Legal Amazon: Prices or Policies? Climate policy initiative. Working paper, 2012. Disponível em:

http://climatepolicyinitiative.org/publication/deforestation-slowdown-in-the-legal-amazon-prices-orpolicie/. Acesso em: 02 de outubro de 2012.

BARONA, E. et al. The role of pasture and soybean in deforestation of the Brazilian Amazon. Environ. Res. Lett., vol. 5, 2010.

CARVAlHO, T. S. Uso do Solo e Desmatamento nas Regiões da Amazônia Legal Brasileira: condicionantes econômicos e impactos de políticas públicas, 2014, 219 p. (Tese de Doutorado). Belo Horizonte: Centro de Desenvolvimento e Planejamento Regional (Cedeplar) Universidade Federal de Minas Gerais, 2014.

CATTANEO, A. Deforestation in the Brazilian Amazon: Comparing the impacts of Macroeconomics Shocks, Land Tenure, and Technological Change. Land Economics, vol. 77, n.2, p. 219-140, 2001.

CATTANEO, A. Balancing Agricultural Development and Deforestation in the Brazilian Amazon. Research Report 129, International Food Policy Research Institute, Washington D. C., 2002.

DINIZ, T. B. Impactos socioeconômicos do Código Florestal Brasileiro: uma discussão à luz de um modelo de equilíbrio geral computável, 2012, 113 p. (Dissertação de Mestrado). São Paulo: Universidade de São Paulo - Escola Superior de Agricultura "Luiz de Queiroz", 2012.

DIXON, P. B. et al. ORANI: A Multisectoral Model of the Australian Economy. Amsterdam: NorthHolland, 1982. 372 p.

FACHINELLO, A. L. Avaliação do impacto econômico de possíveis surtos da gripe aviária no Brasil: uma análise de equilíbrio geral computável, 2008, 161 p. (Tese de Doutorado). São Paulo: Universidade de São Paulo - Escola Superior de Agricultura "Luiz de Queiroz", 2008.

FARIAS, W. R. Modelagem e Avaliação de Fenômenos Relacionados ao Uso da Terra no Brasil, 2012, 275 p. (Tese de Doutorado). São Paulo: Universidade de São Paulo, 2012.

FEARNSIDE, P. M. Deforestation in Brazilian Amazonia: history, rates and consequences. Conservation Biology, vol. 19, n. 3, p. 680-688, 2005.

FERREIRA FILHO, J. B.; HORRIDGE, J. M. The Doha Round, Poverty and Regional Inequality in Brazil. IN: HERTEL, T. W. (eds.). Putting Development Back Into the Doha Agenda: Poverty

Impacts of a WTO Agreement. Washington DC: The International Bank of Reconstruction and Development, Palgrave, McMillan, 2006. 
FERREIRA FILHO, J. B.; HORRIDGE, J. M. Would World Agricultural Trade Liberalization Help the Poor of Brazil? IN: ANDERSON, K. et al. (eds). Agricultural Price Distortions, Inequality and Poverty. Forthcoming., 2008.

FERREIRA FILHO, J. B.; HORRIDGE, J. M. Climate Change Impacts on Agricultural and Internal Migrations in Brazil. In: 13th Annual Conference on Global Economic Analysis, Penang, Malaysia, 2010.

FERREIRA FILHO, J. B.; HORRIDGE, J. M. Climate Change Impacts on Agriculture and Internal Migrations in Brazil. IN: $14^{\text {th }}$ Annual Conference on Global Economic Analysis 2011, Venice Proceedings of the $14^{\text {th }}$ Annual Conference on Global Economic Analysis, 2011.

FERREIRA FILHO, J. B.; HORRIDGE, J. M. Endogenous Land Use and Supply Security in Brazil. General Paper $n^{0}$ G-229, Centre of Policy Studies, CoPS, Monash, 2012.

FERREIRA FILHO, J. B.; HORRIDGE, J. M. Ethanol expansion and indirect land use change in Brazil. Land Use Policy, vol. 36, p. 595-604, 2014.

FERREIRA FILHO, J. B. et al. Tax reform, income distribution and poverty in Brazil: a general equilibrium analysis, MPIA Working Paper 2007-26, Poverty and Economic Policy Research Network PEP-NET, Québec, 2007.

FERREIRA, A. M. M.; SALATI, E. Forças de transformação do ecossistema amazônico. Estudos Avançados, vol. 19, n. 54, 2005.

FOOD AND AGRICULTURE ORGANIZATION OF THE UNITED NATIONS (FAO). Global Forest Resources Assessment 2010. Food and Agriculture Organization of the United Nations, Rome, 2010.

FOOD AND AGRICULTURE ORGANIZATION OF THE UNITED NATIONS (FAO). World Agriculture: towards 2015/2030. Earthscan Publications Ltda: UK, 2003, 444 p.

GASQUES, J.G.; BASTOS, E.T.; BACCHI, M.R.P. Produtividade e Fontes de Crescimento da Agricultura Brasileira. In: de NEGRI. J.; KUBOTA, L. (Eds.) Políticas de Incentivo à Inovação Tecnológica. Brasilia: Instituto de Pesquisa Econômica Aplicada. 2008 (Disponível em: http://www.ipea.gov.br/sites/000/2/livros/inovacaotecnologica/capitulo11.pdf)

GOUVELlO, C. (Ed.) Estudo de Baixo Carbono para o Brasil. 2010. Disponível em:

<http://siteresources.worldbank.org/BRAZILINPOREXTN/Resources/38171661276778791019/Relatorio _Principal_integra_Portugues.pdf> Acesso em: 5 de Setembro de 2012.

HORRIDGE, M. ORANI-G: a General Equilibrium Model of the Australian Economy. Working Paper OP-93. Cops/Impact: Centre of Policy Studies, Monash University, 2000. Disponível em:<www.monash.edu.au/policy/elecpapr/op93.htm>.

HORRIGDE, M. Preparing a TERM bottom-up regional database. Preliminary Draft, Centre of Policy Studies, Monash University, 2006.

HORRIDGE, J. M. et al. The Impact of the 2002-2003 Drought on Australia. Journal of Policy Modeling, v. 27, n. 3, 2005/4, p. 285-308, 2005.

HORRIDGE, J. M.; WITTWER, G. The economic impacts of a construction project, using SinoTERM, a multi-regional CGE model of China. China Economic Review, vol.19, n.4, p. 628-634, 2008.

HORRIDGE, J. M.; WITTWER, G. A multi-regional representation of China's agricultural sectors, China Agricultural Economic Review, vol. 1, n. 4, p. 420-434, 2009.

HUGHTON, R. A. Tropical deforestation as a source of greenhouse gases. IN: MOUTINHO, P.; SCHWARTZMAN, S. (Eds.). Tropical Deforestation and Climate Change. Instituto de Pesquisa Ambiental da Amazônia (IPAM) e Environmental Defense (ED), p 13-22, 2005. 
INSTITUTO DO HOMEM E MEIO AMBIENTE DA AMAZÔNIA (iMAZON); O aumento no Desmatamento na Amazônia em 2013: um ponto fora da curva ou fora de controle?, 2013. Disponível em: http://www.imazon.org.br/publicacoes/outros/o-aumento-no-desmatamento-na-amazonia-em-2013um-ponto-fora-da-curva-ou-fora-de-controle. Acesso em: 12 jan. 2013.

INSTITUTO BRASILEIRO DE GEOGRAFIA E ESTATÍSTICA (IBGE). Censo Agropecuário 2006. Rio de Janeiro: IBGE, 2006.

INSTITUTO NACIONAL DE PESQUISAS ESPACIAIS (INPE); COORDENADORIA GERAL OBSERVAÇÃO DA TERRA PROGRAMA AMAZÔNIA - PROJETO PRODES. Metodologia para $o$ Cálculo da Taxa Anual de Desmatamento na Amazônia Legal, outubro de 2013.

INSTITUTO DE PESQUISA ECONÔMICA APLICADA (IPEA). Código florestal: implicações do PL 1876/99 nas áreas de reserva legal. Comunicados do IPEA. n. 96. 2011.

KRUGMAN, P. Scale Economics, product differentiation, and the pattern of trade, American Economic Review, v. 70, 1980.

MACEDO, D. C. et al. Cropland Expansion changes deforestation dynamics in the Southern Brazilian Amazon. PNAS, vol. 103, n. 39, p. 14637-14641, 2012.

MARGULIS, S. Causas do desmatamento da Amazônia brasileira. Brasília: Banco Mundial, 2003. $100 \mathrm{p}$.

MERTENS, B. et al. Crossing spatial analyses and livestock economics to understand deforestation process in Brazilian Amazon: the case of São Felix do Xingu in South Pará. Agricultural Economics, $\mathrm{n}$. 27, p. 269-294, 2002.

MILLER, R.; BLAIR, P. Input-Output analysis: foundations and extensions. New Jersey: PrenticeHall, 2009. 782p.

MINISTÉRIO DE CIÊNCIA E TECNOLOGIA (MCT). Inventário Brasileiro de Emissões Antrópicas por Fontes e Remoções por Sumidouros de Gases de Efeito Estufa não Controlados pelo Protocolo de Montreal. Brasília: Ministério de Ciência e Tecnologia, 2010.

MINISTÉRIO DO MEIO AMBIENTE (MMA). Plano de Prevenção e Controle do Desmatamento na Amazônia. 2012. Disponível em: <http://www.mma.gov.br/florestas/controle-e-

preven\%C3\%A7\%C3\%A3o-dodesmatamento/plano-de-a\%C3\%A7\%C3\%A3o-para-amaz\%C3\%B4niappcdam> Acesso em: 5 de setembro de 2012.

MINISTÉRIO DO PLANEJAMENTO, ORÇAMENTO E GESTÃO. Impactos Econômicos da Carteira de Investimentos. In: Estudo da Dimensão Territorial para o Planejamento, Volume VI. MPOG, Secretaria de Planejamento e Investimentos Estratégicos, Brasília, 2008.

NASSAR, A. M. Inserção Internacional do Agro - caminho sem volta. O Estado de São Paulo, São Paulo, 16 de março de 2011.

NORDHAUS, W. D. A survey of estimates of the costs of controlling greenhouse gases, Energy Journal, vol. 12, p.37-66, 1991.

PAMBUDI, D.; SMYTH R. Making Indonesia more attractive to foreign investors: A Computable General Equilibrium analysis of reducing the risk premium in Central Java. Review of Urban and Regional Development Studies, vol. 20, n.3, 2008.

PATTANAYAK, S. K. et al. Climate Change and Conservation in Brazil: CGE Evaluation of Health and Wealth Impacts, Economic Geography and Color Maps, vol. 9, n.2, 2009. 
PAVÃO, A. R. Impactos econômicos da introdução do milho Bt11 no Brasil: uma abordagem de equilíbrio geral inter-regional, 2008, 111 p. (Dissertação de Mestrado). São Paulo: Universidade de São Paulo - Escola Superior de Agricultura "Luiz de Queiroz”, 2008.

PERES, C.A. et al. Biodiversity conservation in human-modified Amazonian forest landscapes.

Biological Conservation, n. 143, p. 2314-2327, 2010.

PFAFF, A. S. P. What Drives Deforestation in the Brazilian Amazon? Evidence from satellite and Socioeconomic Data. Journal of Environmental Economics and Management, vol. 37, p. 26-43, 1999.

PNMC (2008). Plano Nacional sobre Mudança do Clima, Brasília, dezembro de 2008.

SANTOS, C. V. Política tributária, nível de atividade econômica e bem-estar: lições de um modelo de equilíbrio geral inter-regional, 2006, 140 p. (Tese de Doutorado). São Paulo: Universidade de São Paulo - Escola Superior de Agricultura "Luiz de Queiroz", 2006.

SOARES-FILHO, B. S. et al. Redução das Emissões de Carbono do Desmatamento no Brasil: O papel do programa Areas Protegidas da Amazônia (ARPA), WWF, 2009. 8 p.

SOARES FILHO, B. S. et al. Cenário de Desmatamento para a Amazônia. Estudos Avançados, v. 19, n. 54, p. 137-152, 2005.

VAN MEIJL, H. et al. The impact of different policy environments on agricultural land use in Europe. Agriculture, Ecosystems \& Environment, vol. 114, p. 21-38, 2006.

WITTWER, G. Economic Modeling of Water. London: Springer, 2012, 186 p.

Appendix - Table VI - Percent Change in Soybean and Cattle Production Cost resulting from the Policy to Control Deforestation (accumulated deviation from 2012 to 2030 relative to baseline)

\begin{tabular}{lccc}
\hline \multicolumn{1}{c}{ Region } & UF & Soybean & Cattle \\
& & & \\
\hline Madeira Guaporé & RO & - & 0.51 \\
Leste Rondoniense & RO & 3.98 & 0.69 \\
\hline Vale Juruá & AC & - & 0.68 \\
Vale Acre & AC & - & 0.78 \\
\hline Norte Amazonense & AM & - & - \\
Sudoeste Amazonense & AM & - & - \\
Centro Amazonense & AM & - & 0.68 \\
Sul Amazonense & AM & 2.09 & - \\
\hline Norte de Roraima & RR & 3.45 & 0.50 \\
Sul de Roraima & RR & 1.89 & 0.37 \\
\hline Baixo Amazonas & PA & 4.94 & 0.84 \\
Marajó & PA & - & 0.63 \\
Metropolitana de Belém & PA & - & 0.40 \\
Nordeste Paraense & PA & 2.76 & 0.67 \\
Sudoeste Paraense & PA & - & 0.38 \\
Sudeste Paraense & PA & 3.33 & 0.48 \\
\hline Norte do Amapá & AP & - & 0.52 \\
Sul do Amapá & AP & - & 0.62 \\
\hline Ocidental de Tocantins & TO & 0.38 & 0.15 \\
Oriental de Tocantins & TO & 0.32 & 0.13 \\
\hline Norte Maranhense & MA & - & 0.68 \\
Oeste Maranhense & MA & - & 0.56 \\
Centro Maranhense & MA & 4.73 & 0.50 \\
Leste Maranhense & MA & 0.55 & 0.20 \\
Sul Maranhense & MA & 0.54 & 0.18 \\
\hline Norte Matogrossense & MT & 3.88 & 0.83 \\
Nordeste Matogrossense & MT & 4.45 & 0.84 \\
Sudoeste Matogrossense & MT & 4.04 & 0.78 \\
Centro-Sul Matogrossense & MT & 0.37 & 0.20 \\
Sudeste Matogrossense & MT & 0.46 & 0.18 \\
\hline Restante do Brasil & - & 0.20 & 0.10 \\
\hline \hline
\end{tabular}

